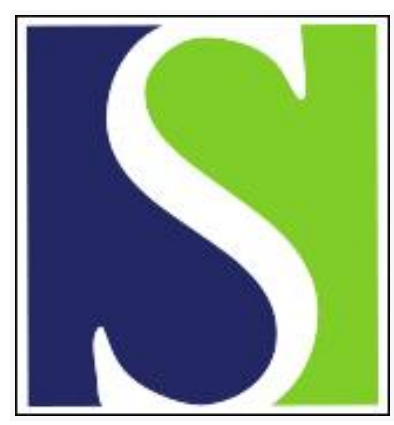

Scand J Work Environ Health 1998;24(2):98-103

https://doi.org/10.5271/sjweh.285

Issue date: Apr 1998

Ectopic pregnancy and occupational exposure of hospital personnel

by Bouyer J, Saurel-Cubizolles M-J, Grenier C, Aussel L, Job-Spira N

Key terms: case-referent study; epidemiology; hospital staff

This article in PubMed: www.ncbi.nlm.nih.gov/pubmed/9630056

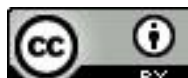




\title{
Ectopic pregnancy and occupational exposure of hospital personnel
}

\author{
by Jean Bouyer, PhD, ${ }^{1}$ Marie-Josèphe Saurel-Cubizolles, PhD, ${ }^{2}$ Catherine Grenier, MD, ${ }^{1}$ \\ Lucette Aussel, ${ }^{1}$ Nadine Job-Spira MD ${ }^{1}$
}

\begin{abstract}
Bouyer J, Saurel-Cubizolles M-J, Grenier C, Aussel L, Job-Spira N. Ectopic pregnancy and occupational exposure of hospital personnel. Scand J Work Environ Health 1998;24(2):98-103.

Objectives An earlier study found a relationship between occupational exposure to antineoplastic drugs and ectopic pregnancy. The present investigation aimed at confirming this finding in a larger and specifically planned study and at analyzing the relationship between ectopic pregnancy and other chemical or physical agents in the hospital work environment.

Methods A case-referent study (140 cases and 279 referents) was carried out in 1995 in a population of women working in hospitals throughout France. The sample size was computed to have an $80 \%$ statistical power to detect a 2 -fold increased risk of ectopic pregnancy (odds ratio 2). Information was collected about past and present work conditions (exposures to antineoplastic drugs, solvents, disinfectants, anesthetic gases and ionizing radiation), and known risk factors of ectopic pregnancy. Multivariate analysis was performed using logistic regression.

Results No significant association between occupational exposure and ectopic pregnancy was found, either when past exposure was considered or when exposure was considered within the 3 months before conception. The relationships remained nonsignificant after adjustment for job category and for the known risk factors of ectopic pregnancy.

Conclusions It was concluded that the results of this study should be interpreted as an absence of relationship between exposure to chemical or physical agents and ectopic pregnancy.
\end{abstract}

Key terms case-referent study, epidemiology, hospital staff.

The incidence of ectopic pregnancy has risen substantially during the past 2 decades, and it is currently $1.5 \%$ of all reported pregnancies in western countries (1). Ectopic pregnancy may have serious consequences, in particular by impairing subsequent fertility $(2,3)$. Several risk factors have been identified (infectious pelvic disease, smoking, tubal surgery, induced conception, age) $(2,4-7)$, but the etiology of one-third of the cases of ectopic pregnancy remains unknown (7).

We hypothesized that zygotic anomalies might be associated with ectopic pregnancy since it is likely that the transport of an abnormal zygote along the uterine tube is less efficient than that of a normal zygote. The relationship between the woman's age and ectopic pregnancy and that between recurrent spontaneous abortions and recurrent ectopic pregnancies $(8,9)$ support this hypothesis. It could be tested indi- rectly by studying the relationship between the risk of ectopic pregnancy and environmental exposure which could increase the proportion of zygotic anomalies.

In a previous paper, we reported a relationship between occupational exposure to antineoplastic drugs and ectopic pregnancy (10). These findings (from a small number of cases) needed to be confirmed by larger studies with the primary objective of assessing this particular relationship. The present paper reports the results of such a study. We tested the hypothesis that occupational exposures would have an effect on the occurrence of ectopic pregnancy. The aim of this study was to analyze the relationship between the occurrence of ectopic pregnancy and occupational exposure in hospitals to agents such as antineoplastic drugs, solvents, disinfectants, anesthetic gases and ionizing radiation, some of which have mutagenic effects.

INSERM U292 (National Research Institute on Health and Medicine, Unit 292), Hôpital de Bicêtre, Le Kremlin-Bicêtre, France.

2 INSERMU149 (National Research Institute on Health and Medicine, Unit 149), Villejuif, France.

Reprint requests to: Dr Jean Bouyer, INSERM U292, Hôpital de Bicêtre, 82 rue du Général Leclerc, 94276 Le Kremlin-Bicêtre Cedex, France. [e-mail: Bouyer@vjf.inserm.fr] 


\section{Subjects and methods}

A case-referent study was carried out in 1995 in a population of women working in hospitals throughout France. The cases and referents were recruited by occupational practitioners during the annual occupational consultation, mandatory in France. The rationale and the design of the study was mailed to 296 occupational practitioners of large and medium-sized hospitals; 104 participated in the study. Recruitment lasted 1 year. The cases were all women working in the participating hospitals who had an ectopic pregnancy between 1 January 1993 and 31 December 1994. For each case, 2 referents were recruited who were the 2 next women visiting the same occupational practitioner and who delivered but had no ectopic pregnancy during the same period.

\section{Sample size}

The required sample size was computed for $80 \%$ statistical power to detect a 2 -fold increased risk of ectopic pregnancy (odds ratio 2) on the assumption that the proportion of exposed women was $20 \%$. We found that 130 cases and 260 referents were required. As about $5 \%$ of working women become pregnant each year, as the rate of ectopic pregnancy is $1.5 \%$ and as an occupational practitioner sees about 1600 women, this study necessitated the participation of at least 70 occupational practitioners. All the women who were asked by their practitioner except 6 ( 4 cases and 2 referents) agreed to participate. Finally, we received questionnaires from 140 cases and 279 referents, and thus the size of the sample was satisfactory.

\section{Data collection}

The occupational practitioner gave each woman a self-administered questionnaire to collect information on age, educational level, marital status, social status, and work conditions, with emphasis on past and present occupational exposure. We also collected data on known risk factors of ectopic pregnancy, medical and surgical history (including sexually transmitted diseases, inflammatory pelvic diseases, appendectomy, and pelvic or tubal surgery), the woman's reproductive history (previous use of birth control, induced conception cycle), sexual activity, and smoking. After having filled out the questionnaire, the women gave it back to the occupational practitioner.

\section{Occupational exposure assessment}

The exposure was self-reported by the women. The following 2 reference periods were investigated: the 3 months preceding the beginning of the pregnancy and the rest of the woman's occupational life. Five distinct kinds of exposure were assessed: antineoplastic drugs, solvents, disinfectants, anesthetic agents and ionizing radiation. The frequency of the exposure to antineoplastic drugs was self-assessed on a 4-point scale, from never to very often. The questionnaire included a list of medical products (all antineoplastic drugs), and the women were allowed to specify the name of the products they used. They also specified whether or not they prepared perfusions, and, if so, the average number per week, and, if they administered perfusions to patients, and the average number per week. For the preparation of perfusions the protective system was described. Solvent exposure (direct use of solvents or work in a room where solvents were used) was self-assessed on a 5-point scale describing daily exposure from never to 4 hours or more a day. The questionnaire included a list of solvents that the respondent had to read and then specified the name of the solvents to which she was exposed. The protective system against solvent exposure, if any, and the tasks using solvents (dilution, cleaning) were described. Exposure to disinfectants was described by a yes or no question asking whether the job included cleaning or sterilization tasks using disinfectants other than solvents. In case of a positive answer the respondent had to specify the name of the chemical agent from a list of disinfectants (other than solvents). Exposure to anesthetic agents (direct use or work in a room where these agents were used or exhaled) was described by a 5 -point scale, in duration, from never to 6 hours or more a day. The name of the anesthetic agents and the system of protection, if any, were specified. Exposure to ionizing radiation was described by a frequency scale, in 4 points, from never to very often. The reasons for exposure to ionizing radiation (radiology, therapy, diagnosis) and the system of protection were reported.

\section{Statistical analysis}

For the analysis, 2 indicators of exposure were considered, a 3-class variable to take past and present exposures into account (exposed in the 3 months before conception, exposed only in the past, never exposed) and a 3-class variable describing the intensity of current exposure (heavy, moderate or none). Generally speaking, heavy exposure corresponded to regular handling or using (daily or often or very often) without a protective device.

The associations between risk factors and ectopic pregnancy were measured by odds ratios. Confounding was addressed with standard methods of stratified analysis (Mantel-Haenszel procedure) (11). Multivariate analysis was performed using unconditional logistic regression. The logistic regression models included job description - nurses, nursing helpers, service workers (mainly cleaners, porters and kitchen staff) and other occupations (mainly clerical staff) — and the known risk factors of ectopic pregnancy - prior genital infection (clinical infectious pelvic disease or Chlamydia trachomatis seropositivity), smoking at the time of conception, and previous pelvic surgery. Furthermore, we considered the woman's age (because the probability of having experienced any investigated past event is dependent on the duration of potential exposure), previous spontaneous abortion, previous induced abortion, induced pregnancy, and previous pregnancies (because the number of previous deliveries tends to be systematically 
greater among cases, as women stop working more often after delivering than after an ectopic pregnancy or an abortion). We did not include the variables prior ectopic pregnancy, prior tubal surgery, or appendectomy in this model, as they are included in the factors prior genital infection and previous pelvic surgery.

\section{Results}

Among the 140 cases, $93 \%$ included tubal ectopic pregnancy, and the treatment was conservative for $40 \% ; 32 \%$ of the cases had an intrauterine device at the time of conception. The mean duration of the pregnancy was 5.6 weeks. Among the 279 referents, the mean duration of gestation was 39.0 weeks and the mean birthweight was $3301 \mathrm{~g}$.

The comparisons between the cases and referents are shown in table 1 for the potential risk factors. Women over 35 years of age, women with at least 1 previous delivery, women with 2 or more previous spontaneous abortions, women with a previous induced abortion, and women with previous pelvic surgery were significantly more numerous in the case group than in the reference group. The established risk factors of ectopic pregnancy (5) were found in this sample with expected magnitudes for the corresponding odds ratios. For instance, the odds ratio associated with previous infectious pelvic disease was 2.48 [95\% confidence interval $(95 \%$ CI) $1.18-5.25]$ and that corresponding to smoking more than 10 cigarettes a day was 2.15 (95\% CI 1.28-3.61).

No significant association between occupational exposure and ectopic pregnancy was found, either when we considered past exposure or when we considered exposure within the 3 months before conception. The relationships between occupational exposures and ectopic pregnancy remained nonsignificant after adjustment for other occupational exposures, for category of job, and for the known risk factors of ectopic pregnancy (table 2). The results were similar when either intensity or frequency of exposure within the 3 months before conception was taken into account (table 3).

\section{Discussion}

For this study, we chose a population of women working in hospitals because it includes a large proportion of women potentially exposed to substances, some of which have known mutagenic effects (12) or have been shown to be associated with adverse pregnancy outcome (13-16). In addition, it allowed comparison of the results with those of our previous study (10). Among the 296 occupational practitioners asked to participate in the study, 163 did not, often because they did not have enough time. This lack of participation was unlikely to have induced selection bias as the participants were spread throughout the country and worked in hospitals of various sizes and as the referents were recruited from the same hospital as the cases.

The reference group was made up only of pregnancies ending in delivery. Thus women with an intrauterine pregnancy who decided to interrupt it were systematically not included. In contrast, the ectopic pregnancy group included women who could have decided to interrupt their pregnancy if it were not ectopic. The absence of induced abortions in the reference group is liable to have induced selection bias into the study of factors associated with the decision to interrupt a pregnancy, such as obstetrical history or age. To limit this bias, a strategy commonly used in the field of epidemiology of ectopic pregnancy was applied, that is, the analysis was conducted among the cases and the referents who were married or living as a couple, and with no contraception at the time of conception (17), the proportion of which was greater among the referents than among the cases because of the large number of women with an intrauterine device among those suffering ectopic pregnancy (in our study it led to a restriction of the analysis to 84 cases and 267 referents). We verified that results concerning occupational exposure were identical with this strategy of analysis.

We did not find any association between exposure to chemical or physical agents at work and ectopic pregnancy. This result could be explained either by a true absence of association or by a lack of statistical power, by recall bias about exposure, or by a level of exposure too low to have a detectable effect.

The lack of statistical power was unlikely as the number of subjects (140 cases and 279 referents) and the proportion of exposed subjects (14\% to $43 \%$ according to the agent table 4) were large enough for a power of $80 \%$. (See the Subjects and Methods section.) Moreover the estimated odds ratios for occupational exposure were generally close to 1 with moderately large confidence intervals. If the absence of statistical significance had been due to a lack of statistical power, higher odds ratios with large confidence intervals would have been expected.

The exposure was evaluated through a self-administered questionnaire, and thus the women's answers could have been inaccurate. A pretest of the questionnaire showed that the women understood the questions clearly and had no difficulties in answering them. Women working in hospitals are generally aware of the products they handle and thus are able to report their exposure without substantial error. Moreover, table 4 shows that the exposures reported were in accordance with the kind of job held by the women (eg, no service workers and only 1 "other" worker declared past or present exposure to antineoplastics), and therefore there was indirect evidence of the absence of reporting bias. We restricted the analysis to nurses and medical staff; these groups are the women who are likely to report their exposures the most accurately. Although the sample was smaller, 
Table 1. Distribution of risk factors for ectopic pregnancy among the cases $(N=140)$ and referents $(N=279)$ and the odds ratios $(O R)$ and $95 \%$ confidence intervals $(95 \% \mathrm{Cl})$.

\begin{tabular}{|c|c|c|c|c|c|c|}
\hline \multirow[t]{2}{*}{ Factors } & \multicolumn{2}{|c|}{ Referents } & \multicolumn{2}{|c|}{ Cases } & \multirow[t]{2}{*}{ Crude OR } & \multirow[t]{2}{*}{$95 \% \mathrm{Cl}$} \\
\hline & N & $\%$ & $\mathrm{~N}$ & $\%$ & & \\
\hline \multicolumn{7}{|l|}{ Previous pelvic infectious disease } \\
\hline $\begin{array}{l}\text { No } \\
\text { Yes }\end{array}$ & $\begin{array}{r}263 \\
14\end{array}$ & $\begin{array}{r}95 \\
5\end{array}$ & $\begin{array}{r}121 \\
16\end{array}$ & $\begin{array}{l}88 \\
12\end{array}$ & $\begin{array}{l}1 \\
2.48\end{array}$ & $1.18-5.25$ \\
\hline \multicolumn{7}{|l|}{$\begin{array}{l}\text { Woman smoking at } \\
\text { the time of conception }\end{array}$} \\
\hline $\begin{array}{l}\text { No } \\
1-9 \text { cigarettes/day } \\
\geq 10 \text { cigarettes/day }\end{array}$ & $\begin{array}{r}204 \\
36 \\
38\end{array}$ & $\begin{array}{l}73 \\
13 \\
14\end{array}$ & $\begin{array}{l}90 \\
14 \\
36\end{array}$ & $\begin{array}{l}64 \\
10 \\
26\end{array}$ & $\begin{array}{l}1 \\
0.88 \\
2.15\end{array}$ & $\begin{array}{l}0.45-1.71 \\
1.28-3.61\end{array}$ \\
\hline \multicolumn{7}{|l|}{ Age } \\
\hline $\begin{array}{l}\leq 24 \text { years } \\
25-29 \text { years } \\
30-34 \text { years } \\
\geq 35 \text { years }\end{array}$ & $\begin{array}{r}22 \\
129 \\
86 \\
41\end{array}$ & $\begin{array}{r}8 \\
46 \\
31 \\
15\end{array}$ & $\begin{array}{r}7 \\
37 \\
45 \\
51\end{array}$ & $\begin{array}{r}5 \\
26 \\
32 \\
37\end{array}$ & $\begin{array}{l}1.11 \\
1 \\
1.82 \\
4.34\end{array}$ & $\begin{array}{l}0.44-2.80 \\
1.09-3.05 \\
2.50-7.52\end{array}$ \\
\hline \multicolumn{7}{|l|}{ Previous deliveries } \\
\hline $\begin{array}{l}0 \\
\geq 1\end{array}$ & $\begin{array}{l}127 \\
149\end{array}$ & $\begin{array}{l}46 \\
54\end{array}$ & $\begin{array}{l}43 \\
96\end{array}$ & $\begin{array}{l}31 \\
69\end{array}$ & $\begin{array}{l}1 \\
1.90\end{array}$ & $1.24-2.93$ \\
\hline \multicolumn{7}{|l|}{ Previous spontaneous abortions } \\
\hline $\begin{array}{l}0 \\
1 \\
\geq 2\end{array}$ & $\begin{array}{r}224 \\
43 \\
8\end{array}$ & $\begin{array}{r}81 \\
16 \\
3\end{array}$ & $\begin{array}{r}107 \\
17 \\
14\end{array}$ & $\begin{array}{l}78 \\
12 \\
10\end{array}$ & $\begin{array}{l}1 \\
0.82 \\
3.66\end{array}$ & $\begin{array}{l}0.45-1.52 \\
1.49-9.00\end{array}$ \\
\hline \multicolumn{7}{|l|}{ Previous induced abortions } \\
\hline $\begin{array}{l}\text { No } \\
\text { Yes }\end{array}$ & $\begin{array}{r}253 \\
22\end{array}$ & $\begin{array}{r}92 \\
8\end{array}$ & $\begin{array}{r}116 \\
21\end{array}$ & $\begin{array}{l}85 \\
15\end{array}$ & $\begin{array}{l}1 \\
2.08\end{array}$ & $1.10-3.94$ \\
\hline \multicolumn{7}{|l|}{ Induced pregnancy } \\
\hline $\begin{array}{l}\text { No } \\
\text { Yes }\end{array}$ & $\begin{array}{r}252 \\
23\end{array}$ & $\begin{array}{r}92 \\
8\end{array}$ & $\begin{array}{r}124 \\
15\end{array}$ & $\begin{array}{l}89 \\
11\end{array}$ & $\begin{array}{l}1 \\
1.33\end{array}$ & $0.67-2.63$ \\
\hline \multicolumn{7}{|l|}{ Previous pelvic surgery } \\
\hline $\begin{array}{l}\text { No } \\
\text { Yes }\end{array}$ & $\begin{array}{r}256 \\
23\end{array}$ & $\begin{array}{r}92 \\
8\end{array}$ & $\begin{array}{r}110 \\
30\end{array}$ & $\begin{array}{l}79 \\
21\end{array}$ & $\begin{array}{l}1 \\
3.04\end{array}$ & $1.69-5.46$ \\
\hline $\begin{array}{l}\text { Exposure to antineoplastic drugs } \\
\text { None } \\
\text { Only in the past } \\
\text { In the } 3 \text { months before conception }\end{array}$ & $\begin{array}{r}218 \\
22 \\
33\end{array}$ & $\begin{array}{r}80 \\
8 \\
12\end{array}$ & $\begin{array}{r}113 \\
15 \\
10\end{array}$ & $\begin{array}{r}82 \\
11 \\
7\end{array}$ & $\begin{array}{l}1 \\
1.32 \\
0.58\end{array}$ & $\begin{array}{l}0.66-2.63 \\
0.28-1.23\end{array}$ \\
\hline \multicolumn{7}{|l|}{ Exposure to solvents } \\
\hline $\begin{array}{l}\text { None } \\
\text { Only in the past } \\
\text { In the } 3 \text { months before conception }\end{array}$ & $\begin{array}{r}177 \\
14 \\
84\end{array}$ & $\begin{array}{r}64 \\
5 \\
31\end{array}$ & $\begin{array}{r}93 \\
6 \\
41\end{array}$ & $\begin{array}{r}67 \\
4 \\
29\end{array}$ & $\begin{array}{l}1 \\
0.82 \\
0.93\end{array}$ & $\begin{array}{l}0.30-2.19 \\
0.59-1.46\end{array}$ \\
\hline \multicolumn{7}{|l|}{ Exposure to disinfectants } \\
\hline $\begin{array}{l}\text { None } \\
\text { Only in the past } \\
\text { In the } 3 \text { months before conception }\end{array}$ & $\begin{array}{r}160 \\
17 \\
98\end{array}$ & $\begin{array}{r}58 \\
6 \\
36\end{array}$ & $\begin{array}{l}74 \\
10 \\
55\end{array}$ & $\begin{array}{r}53 \\
7 \\
40\end{array}$ & $\begin{array}{l}1 \\
1.27 \\
1.21\end{array}$ & $\begin{array}{l}0.56-2.91 \\
0.79-1.87\end{array}$ \\
\hline \multicolumn{7}{|l|}{ Exposure to anesthetic gases } \\
\hline $\begin{array}{l}\text { None } \\
\text { Only in the past } \\
\text { In the } 3 \text { months before conception }\end{array}$ & $\begin{array}{r}234 \\
11 \\
29\end{array}$ & $\begin{array}{r}85 \\
4 \\
11\end{array}$ & $\begin{array}{r}120 \\
6 \\
12\end{array}$ & $\begin{array}{r}87 \\
4 \\
9\end{array}$ & $\begin{array}{l}1 \\
1.06 \\
0.81\end{array}$ & $\begin{array}{l}0.38-2.95 \\
0.40-1.64\end{array}$ \\
\hline \multicolumn{7}{|l|}{ Exposure to ionizing radiation } \\
\hline $\begin{array}{l}\text { None } \\
\text { Only in the past } \\
\text { In the } 3 \text { months before conception }\end{array}$ & $\begin{array}{r}185 \\
13 \\
77\end{array}$ & $\begin{array}{r}67 \\
5 \\
28\end{array}$ & $\begin{array}{r}96 \\
5 \\
38\end{array}$ & $\begin{array}{r}69 \\
4 \\
27\end{array}$ & $\begin{array}{l}1 \\
0.74 \\
0.95\end{array}$ & $\begin{array}{l}0.26-2.14 \\
0.60-1.51\end{array}$ \\
\hline
\end{tabular}

the results were similar. There was no trend between the occupational exposure level and the risk of ectopic pregnancy. Furthermore, if there had been recall bias, it is likely that it would have been an underreporting of exposure among the referents, and it could not explain our results $(18,19)$.

The level of the exposure of women working in hospitals may be too low nowadays to cause a substantial increase in ectopic pregnancy risk. We considered this drawback by excluding the women who were seldom exposed or only ex- posed when using a protective device from the exposed group. Thus our exposed group contained only women with a medium or high level of exposure. Moreover, when we included the intensity and the frequency of exposure in the analysis, we did not find any trend for the risk of ectopic pregnancy. Occupational exposures in similar populations have previously been studied by other teams. Relationships with adverse pregnancy outcomes (especially spontaneous abortion) have been found with odds ratios of around 2 for 
Table 2. Relationships between occupational exposures and ectopic pregnancy: adjusted odds ratios (OR) and $95 \%$ confidence intervals $(95 \% \mathrm{Cl})$.

\begin{tabular}{|c|c|c|}
\hline Occupational exposure & Adjusted ORa & $95 \% \mathrm{Cl}$ \\
\hline \multicolumn{3}{|l|}{ Antineoplastic drugs } \\
\hline None & 1 & \\
\hline Only in the past & 1.56 & $0.65-3.72$ \\
\hline In the 3 months before conception & 0.95 & $0.39-2.31$ \\
\hline \multicolumn{3}{|l|}{ Solvents } \\
\hline None & 1 & \\
\hline Only in the past & 0.51 & $0.14-1.96$ \\
\hline In the 3 months before conception & 1.04 & $0.59-1.86$ \\
\hline \multicolumn{3}{|l|}{ Disinfectants } \\
\hline None & 1 & \\
\hline Only in the past & 1.77 & $0.57-5.54$ \\
\hline In the 3 months before conception & 1.41 & $0.82-2.42$ \\
\hline \multicolumn{3}{|l|}{ Anesthetic gases } \\
\hline None & 1 & \\
\hline Only in the past & 0.95 & $0.25-3.53$ \\
\hline In the 3 months before conception & 0.78 & $0.31-1.95$ \\
\hline \multicolumn{3}{|l|}{ Ionizing radiation } \\
\hline None & 1 & \\
\hline Only in the past & 0.69 & $0.19-2.56$ \\
\hline In the 3 months before conception & 1.43 & $0.77-2.64$ \\
\hline \multicolumn{3}{|c|}{$\begin{array}{l}\text { Each odds ratio has been adjusted for the other exposures in the table } \\
\text { and for the category of occupation (nurses, nursing helpers, service } \\
\text { workers, other), woman's age, previous deliveries, previous pelvic } \\
\text { infectious disease, woman smoking at the time of conception, previous } \\
\text { spontaneous abortions, previous induced abortions, induced pregnancy, } \\
\text { and previous pelvic surgery. }\end{array}$} \\
\hline
\end{tabular}

Table 3. Relationships between frequency and intensity of occupational exposures and ectopic pregnancy: adjusted odds ratios (OR) and $95 \%$ confidence intervals $(95 \% \mathrm{Cl})$.

\begin{tabular}{|c|c|c|}
\hline $\begin{array}{l}\text { Occupational exposure in the } 3 \\
\text { months before conception }\end{array}$ & Adjusted $0 \mathrm{R}^{\mathrm{a}}$ & $95 \% \mathrm{Cl}$ \\
\hline \multicolumn{3}{|l|}{ Antineoplastic drugs } \\
\hline $\begin{array}{l}\text { None } \\
\text { Moderate } \\
\text { Heaw }\end{array}$ & $\begin{array}{l}1 \\
1.69 \\
0.22\end{array}$ & $\begin{array}{l}0.60-4.71 \\
0.04-1.28\end{array}$ \\
\hline \multicolumn{3}{|l|}{ Solvents } \\
\hline $\begin{array}{l}\text { None } \\
\text { Moderate } \\
\text { Heawy }\end{array}$ & $\begin{array}{l}1 \\
0.93 \\
1.49\end{array}$ & $\begin{array}{l}0.47-1.86 \\
0.63-3.54\end{array}$ \\
\hline \multicolumn{3}{|l|}{ Disinfectants } \\
\hline $\begin{array}{l}\text { No } \\
\text { Yes }\end{array}$ & $\begin{array}{l}1 \\
1.34\end{array}$ & $0.78-2.31$ \\
\hline \multicolumn{3}{|l|}{ Anesthetic gases } \\
\hline $\begin{array}{l}\text { None } \\
\text { Moderate } \\
\text { Heavy }\end{array}$ & $\begin{array}{l}1 \\
0.50 \\
2.80\end{array}$ & $\begin{array}{l}0.17-1.49 \\
0.62-12.7\end{array}$ \\
\hline \multicolumn{3}{|l|}{ Ionizing radiation } \\
\hline $\begin{array}{l}\text { None } \\
\text { Moderate } \\
\text { Heawy }\end{array}$ & $\begin{array}{l}1 \\
1.48 \\
1.98\end{array}$ & $\begin{array}{l}0.77-2.83 \\
0.56-7.06\end{array}$ \\
\hline \multicolumn{3}{|c|}{$\begin{array}{l}\text { Each odds ratio has been adjusted for the other exposures in the table } \\
\text { and for category of occupation (nurses, nursing helpers, service } \\
\text { workers, other), woman's age, previous deliveries, previous pelvic } \\
\text { infectious disease, woman smoking at the time of conception, previous } \\
\text { spontaneous abortions, previous induced abortions, induced pregnancy, } \\
\text { and previous pelvic surgery. }\end{array}$} \\
\hline
\end{tabular}

Table 4. Occupational exposure in the 3 months before the conception or previously according to job category (cases and referents together).

\begin{tabular}{|c|c|c|c|c|c|}
\hline Exposure & $\begin{array}{c}\text { Total } \\
(N=419) \\
(\%)\end{array}$ & $\begin{array}{c}\text { Nurses } \\
(N=207) \\
(\%)\end{array}$ & $\begin{array}{c}\text { Nursing } \\
\text { helpers } \\
(\mathbb{N}=99) \\
(\%)\end{array}$ & $\begin{array}{c}\text { Service } \\
\text { workers }^{b} \\
(N=64) \\
(\%)\end{array}$ & $\begin{array}{c}\text { Other } \\
\text { occupationsc } \\
(\mathrm{N}=49) \\
(\%)\end{array}$ \\
\hline $\begin{array}{l}\text { Antineoplastic drugs } \\
\text { Solvents } \\
\text { Disinfectants } \\
\text { Anesthetic gases } \\
\text { lonizing radiation }\end{array}$ & $\begin{array}{l}19.5 \\
34.9 \\
43.5 \\
14.1 \\
32.1\end{array}$ & $\begin{array}{l}37.9 \\
45.2 \\
44.9 \\
25.0 \\
49.5\end{array}$ & $\begin{array}{r}2.0 \\
29.9 \\
56.7 \\
4.1 \\
18.5\end{array}$ & $\begin{array}{r}0.0 \\
34.9 \\
50.8 \\
4.8 \\
14.5\end{array}$ & $\begin{array}{l}2.0 \\
2.0 \\
2.0 \\
0.0 \\
8.2\end{array}$ \\
\hline
\end{tabular}

a Nurses: nurses (166), laboratory assistants (10), X ray technicians (12), midwives (6), medical doctors (6), nursery nurses (7).

- Service workers: nonnursing care workers (58), kitchen staff (4), cleaning staff (2).

c Other occupations: clerical staff (38), psychologists (3), social workers (2), managers (4), speech therapists (2).

various types of exposure: antineoplastic drugs (20), solvents (21), anesthetic gases (22,23), and ethylene oxide (24). This phenomenon tends to suggest that the level of exposure that we studied is prone to have detectable adverse effects. The absence of a significant relationship between exposure and ectopic pregnancy in our study is thus probably due to the relationship being weak or nonexistent rather than to the level of exposure being too low for effect.

We thus conclude that our results should be interpreted as an absence of a relationship between exposure to chemical and physical agents (which include some mutagens) and ectopic pregnancy. To explain the discrepancy with the results of our previous study, we suggest that either the earlier results were observed by chance or the levels of occupation- al exposures were higher, as the pregnancies studied took place some 10 to 20 years earlier.

Finally, the hypothesis that zygotic anomalies could be a cause of ectopic pregnancy is not supported by our study, albeit indirect. A recent paper (25) reached the same conclusion in studying directly the karyotype of ectopic pregnancies, but this study included a very small number of observations.

\section{Acknowledgments}

We thank Dr P Paubel (central pharmacy of Paris hospitals) for his help in identifying the precise chemical nature of the 
products handled by the women responding to our questionnaire, and the 133 occupational practitioners who participated in this study.

\section{References}

1. Coste J, Job-Spira N, Aublet-Cuvelier B, Germain E, Glowaczower $\mathrm{E}$, Fernandez $\mathrm{H}$, et al. Incidence of ectopic pregnancy: first results of a population-based register in France. Hum Reprod 1994;9:742 - 5.

2. Chow WH, Daling JR, Cates W, Greenberg RS. Epidemiology of ectopic pregnancy. Epidemiol Rev 1987;9:70—94.

3. Job-Spira N, Bouyer J, Pouly JL, Germain E, Coste J, Aublet-Cuvelier B, et al. Fertility after ectopic pregnancy: first results of a population-based cohort study in France. Hum Reprod 1996;11:99-104

4. Handler A, Davis F, Ferr C, Yeko T. The relationship of smoking and ectopic pregnancy. Am J Public Health 1989;79:1239—42.

5. Coste J, Job-Spira N, Fernandez H, Papiernik E, Spira A. Risk factor for ectopic pregnancy: a case control study in France, with specia focus on infectious factors. Am J Epidemiol 1991;133:839_49.

6. Coste J, Job-Spira N, Fernandez H. Increased risk of ectopic pregnancy with cigarette smoking. Am J Public Health 1991;81:199-201.

7. Job-Spira N, Collet P, Coste J, Brémond A, Laumon B. Facteurs de risque de la grossesse extra-utérine: résultats d'une enquête cas-témoins dans la région Rhône-Alpes. Contraception Fertil Sex $1993 ; 21: 307-12$.

8. Bouyer J, Tharaux-Deneux C, Job-Spira N, Coste J. Grossesse extrautérine: des facteurs liés à des anomalies de l'œuf? Rev Epidemiol Sante Publique 1996;44:101-10.

9. Job-Spira N, Coste J, Bouyer J, Tharaux-Deneux C, Fernandez H Chromosomal abnormalities and ectopic pregnancy? new directions for etiological research. Hum Reprod 1996;11(2):239-42.

10. Saurel-Cubizolles MJ, Job-Spira N, Estryn-Behar M. Ectopic pregnancy and occupational exposure to antineoplastic drugs. Lancet 1993;341:1169-71.

11. Kleinbaum DG, Kupper LL, Morgenstem $H$. Epidemiologic research: principles and quantitative methods. Belmont (CA): Lifetime Learning Publications, 1982.

12. Sieber SM, Adamson RH. Toxicity of antineoplastic agents in man: chromosomal aberrations, antifertility effects, congenital malformations and carcinogenic potential. Adv Cancer Res 1975;22:57-155.
13. Florack EIM, Zielhuis GA. Occupational ethylene oxide exposure and reproduction. Int Arch Occup Environ Health 1990;62:273-7.

14. Guirguis SS, Pelmear PL, Roy ML, Wong L. Health effects associated with exposure to anaesthetic gases in Ontario hospital personnel. Br J Ind Med 1990;47:490-27.

15. Taskinen H, Kyyrönen P, Hemminki K, Hoikkala M, Lajunen K, Lindbohm ML. Laboratory work and pregnancy outcome. J Occup Med 1994;36:311-9.

16. Ahlborg G, Hemminki K. Reproductive effects of chemical exposures in health professions. J Occup Environ Med 1995;37: 95761.

17. Weiss NS, Daling JR, Chow WH. Control definition in case-control studies of ectopic pregnancy. Am J Public Health 1985;75:67-8.

18. Neutra RR, Swan SH, Hertz-Piciotto, Windham GC, Wrensch M, Shaw GM, et al. Potential sources of bias and confounding in environmental epidemiologic studies of pregnancy outcome. Epidemiology 1992;3:134-42.

19. Farrow A, Farrow SC, Little R, Golding J, the ALSPAC study team. The repeatability of self-reported exposure after miscarriage. Int J Epidemiol 1996;25:797-806.

20. Stiicker I, Caillard J-F, Collin R, Gout M, Poyen D, Hémon D. Risk of spontaneous abortion among nurses handling antineoplastic drugs. Scand J Work Environ Health 1990;16:102_-7.

21. Lindbohm M-L, Taskinen H, Kyyrönen P, Sallmén M, Anttila A, Hemminki K. Effects of parental occupational exposure to solvents and lead on spontaneous abortion. Scand J Work Environ Health 1992;18 suppl 2:37-9.

22. Rowland AS, Baird DD, Shore DL, Weinberg CR, Savitz DA, Wil cox AJ. Nitrous oxide and spontaneous abortion in female dental assistants. Am J Epidemiol 1995;141:531-8.

23. Saurel-Cubizolles MJ, Hays M, Estryn-Behar M. Work in operating rooms and pregnancy outcome among nurses. Int Arch Occup Environ Health 1994;66:235-41.

24. Rowland AS, Baird DD, Shore DL, Darden B, Wilcox AJ. Ethylene oxide exposure may increase the risk of spontaneous abottion, preterm birth, and postterm birth. Epidemiology 1996;7:363-8.

25. Goddijn M, van der Veen F, Schuring-Blom GH, Ankum WM, Leschot NJL. Cytogenetic characteristics of ectopic pregnancy. Hum Reprod 1996;11(12):2769-71.

Received for publication: 6 May 1997 